\title{
The effect and mechanism of low intensity focused ultrasound in the treatment of Parkinson's disease
}

\author{
Ling Long ${ }^{1}$, yunxiao zhong ${ }^{1}$, Xiaodong $\mathrm{Cai}^{1}$, Jinchi Liao ${ }^{1}, \mathrm{Xu} \mathrm{Liu}{ }^{1}$, and Yiying Huang ${ }^{1}$ \\ ${ }^{1}$ Sun Yat-Sen University
}

July 8, 2021

\begin{abstract}
ABSTRACT Parkinson's disease (PD) is a chronic, progressive, neurodegenerative disease. A new brain-stimulation method, low-intensity focused ultrasound (LIFUS), has been shown to improve PD-associated motor symptoms and permeabilize the blood-brain barrier. LIFUS is especially attractive due to its non-invasive nature and represents a treatment option that could be incorporated into the future treatment of neurodegenerative diseases, including PD. In this paper, we describe the current state and future outlook of LIFUS for the treatment of PD. We also focus on the stimulation principles that underly the effects of LIFUS during PD treatment. The safety and limitations of LIFUS are also discussed.
\end{abstract}

The effect and mechanism of low intensity focused ultrasound in the treatment of Parkinson's disease

Yun-Xiao Zhonga,1, Jin-Chi Liao ${ }^{\mathrm{a}, 1}, \mathrm{Xv}_{\mathrm{Liu}}^{\mathrm{a}}$, Yi-Ying Huang ${ }^{\mathrm{a}}$, Xiao-Dong Cai ${ }^{\mathrm{b}^{*}}$, Ling Longa ${ }^{*}$

a Department of Neurology, The Third Affiliated Hospital of Sun Yat-sen University, Guangzhou, China

b Department of Neurology, The Sixth Affiliated Hospital of Sun Yat-sen University, Guangzhou, China

* Corresponding author. Department of Neurology, The Third Affiliated Hospital of Sun Yat-sen University, Guangzhou 510630, China.

E-mail address:longl3@mail.sysu.edu.cn,linglinglively@126.com (L. Long) andcaixd3@mail.sysu.edu.cn(X. Cai)

1 These authors contributed equally to this work.

\section{ABSTRACT}

Parkinson's disease (PD) is a chronic, progressive, neurodegenerative disease. A new brain-stimulation method, low-intensity focused ultrasound (LIFUS), has been shown to improve PD-associated motor symptoms and permeabilize the blood-brain barrier. LIFUS is especially attractive due to its non-invasive nature and represents a treatment option that could be incorporated into the future treatment of neurodegenerative diseases, including PD. In this paper, we describe the current state and future outlook of LIFUS for the treatment of PD. We also focus on the stimulation principles that underly the effects of LIFUS during PD treatment. The safety and limitations of LIFUS are also discussed.

Keywords: Parkinson's disease; low-intensity focused ultrasound; blood-brain barrier; stimulation mechanism

\section{Introduction}


Parkinson's disease (PD) is a common, chronic, progressive, neurodegenerative disease characterized by the selective loss of dopaminergic neurons in the substantia nigra (SN) and the development of proteinaceous amyloid fibrils comprised primarily of $\alpha$-synuclein (Trist, Hare, \& Double, 2019). Currently, the only treatments available for PD aim to improve dyskinesia by replacing dopamine (Qian et al., 2020). However, improvements in the understanding of the etiology of these diseases have allowed the development of novel therapeutic approaches. Many potential pharmacological, non-pharmacological, and neurosurgical treatment methods have been explored to address various pathological mechanisms, including gene therapy, oxidative stress reduction, cell therapy, disease modification therapies, and new delivery methods for both new and existing treatments. However, many of the developed treatment methods have been unable to penetrate the blood-brain barrier (BBB), which can severely hamper their effectiveness. The BBB prevents the passage of many molecules through paracellular channels, forming a tightly regulated neurovascular unit that includes the cerebrovascular endothelium, arachnoid and choroid epithelia, which act together to maintain normal brain functions. Therefore, the physiological functions of the BBB must be temporarily disrupted to allow the delivery of macromolecular diagnostic or therapeutic substances. Preclinical literature has increasingly demonstrated that low-intensity transcranial ultrasound stimulation (TUS), which has a high spatial resolution and high penetration depth, may represent a new, non-invasive, neuromodulatory technique (di Biase, Falato, \& Di Lazzaro, 2019).

Focused ultrasound (FUS) under certain conditions has been shown to reversibly permeabilize the BBB, without ablation, suggesting that FUS-induced BBB disruption might provide an avenue for the delivery of drugs, antibodies, nanoparticles, gene therapy, and even cells to the brain, providing increasing the range of options for therapeutic macromolecules that can be used to treat neurological diseases (Ellis \& Fell, 2017; Xie, Shen, Anraku, Kataoka, \& Chen, 2019). This review synthesizes the currently available information and provides a comprehensive description of the animal and human findings regarding the use of low-intensity focused ultrasound (LIFUS) to treat primary PD and other degenerative diseases associated with parkinsonian symptoms.

\section{LIFUS: a potential surgical technique for non-invasive intervention}

Ultrasound (US) waves are mechanical undulations above the upper audible limit of the human ear $(>20$ kHz) (Bowary \& Greenberg, 2018). In 1955, Fry predicted that FUS would have a major impact on neurology (Fry, Barnard, Fry, Krumins, \& Brennan, 1955). Using a specially designed transducer, FUS can be used to aim US waves at a focal point with a diameter of only a few millimeters. To date, FUS has been shown to have significant effects on Alzheimer's disease (Meng et al., 2017), depression (Zhang et al., 2019), essential tremor (Lipsman et al., 2013), obsessive-compulsive disorder (Krishna, Sammartino, \& Rezai, 2018) and other disease states and has been used to investigate the structure and function of brain circuitry (Kubanek et al., 2020). Transcranial FUS can be divided into two modalities: high-intensity FUS (HIFU) and LIFUS. HIFU refers to the use of intensities that exceed $200 \mathrm{~W} / \mathrm{cm}^{2}$, whereas LIFUS typically refers to the use of intensities below $100 \mathrm{~W} / \mathrm{cm}^{2}$ (Panczykowski, Monaco, \& Friedlander, 2014). LIFUS utilizes a spatial resolution on the millimeter scale and has the potential to target subcortical structures through an intact skull to a depth of more than $10 \mathrm{~cm}$ (Baek, Pahk, \& Kim, 2017). LIFUS has become an area of intense interest in many research fields (Lee, Fomenko, \& Lozano, 2019). Currently available surgical treatment for PD, including deep brain stimulation (DBS) (Miocinovic et al., 2020), levodopa-carbidopa intestinal gel treatments (Fabbri et al., 2020), the HIFU-mediated burning of the thalamus (Bauer et al., 2014), and other treatments, are highly invasive. LIFUS has facilitated achievements in tumor treatment (Son et al., 2020), stem cell research (Liu, Ullah, Concepcion, Dahl, \& Thakor, 2020), neurological research (Karmacharya et al., 2015; Yang et al., 2020) and many other fields. In both animal studies and human studies, LIFUS has attracted increasing attention as a non-invasive neuromodulation method for use in PD research.

The specific mechanisms associated with LIFUS in the treatment of PD

Potential mechanisms associated with improved PD-associated motor symptoms after LIFUS stimulation

When applied as a brain stimulation method, LIFUS has been shown to decrease the resistance of the BBB 
and improve PD-associated motor symptoms (Lewitt, Lipsman, \& Kordower, 2019; Meng et al., 2018). Qian $\mathrm{Li}$ (Li et al., 2012) et al. demonstrated that DBS acts on the disruption of abnormal neural activities in the motor cortex in PD by antidromically activating the layer $\mathrm{V}$ corticofugal projection neurons in the motor cortex through the stimulation of the subthalamic nucleus (STN). Zhou (Zhou, Niu, \& Xia et al., 2019) et al. examined a PD mouse model induced by 1-methyl-4-phenyl-1,2,3,6-tetrahydropyridine (MPTP) treatment and applied 7 days of low-intensity pulsed ultrasound (LIPUS) $(800 \mathrm{kHz}, 10 \%$ duty cycle (DC), 100Hz pulse repetition frequency (PRF), $10 \mathrm{~s}$ interstimulus interval (ISI), $40 \mathrm{~min} /$ day) to the PD model mice and found that seven cumulative days of LIPUS stimulation of motor cortex ameliorated parkinsonian motor deficits and enhance striatal T-SOD and GSH-PX. Yuan (Yuan et al., 2020) et al. applied LIFUS (500 kHz, 5\% DC, $1 \mathrm{kHz}$ PRF,1s ISI) in PD mice from day 1 to 14 in the PD+TUS group. The results demonstrated that ultrasound stimulation was able to improve the motor function of PD mice. The STN was included in their ultrasound stimulation zone, but not the motor cortex which suggested that LIFUS may act directly on the STN to stimulate neuronal activity, which may be beneficial for the excitation and transmission of dopamine to neurons in the SN, resulting in the same therapeutic effects as the pharmacological treatment of Parkinson's disease (Connolly \& Lang, 2014).

There are also related documents pointed out that LIFUS can regulate other clinically relevant targets, hippocampus, thalamic corticospinal and thalamic cortical pathways (Dallapiazza et al., 2018). It is possible to improve motor function by stimulating the STN-motor cortex circuit. A study demonstrated that transcranial pulsed US was capable of stimulating intact brain circuits, increased synchronous activity and elevated BDNF expression patterns (Tufail et al., 2010). Lin (Lin, Chen, Lu, Liu, \& Yang, 2015) and Yang (Yang, Lu, Lin, Chang, \& Huang, 2015)et al. found that LIFUS application increased BDNF levels in vivo and in vitro, which strongly suggested that LIFUS might have positive effects for the treatment of neurodegenerative diseases. Liu (Liu, Lai, Chen, \& Yang, 2017) et al. found that Ultrasound enhanced the expression of BDNF in astrocyte through activation of the activation of NF- $x \mathrm{~B}$ via the TrkB/PI3K/Akt and calcium/CaMK signaling pathways. The specific mechanism of LIFUS improving the motor symptoms of PD animal models and increasing the expression of neurotrophic factors still needs further study. In adult mice, LIPUS with microbubbles significantly increased the number of proliferating cells and new neurons in the dorsal dentate gyrus of the hippocampus (Scarcelli et al., 2014). LIPUS has also been shown to promote axon regeneration in injured nerves (Chang, Hsu, Lin, Chang, \& Chang, 2005; Jiang et al., 2016). These findings suggest that the technique may play a beneficial role in the treatment of degenerative brain diseases by regeneration and repair of nerve cells. Further investigations are warranted to elucidate the mechanisms underlying US-associated neuromodulation.

However, studies also have indicated that LIFUS can directly induce neuronal responses and mediate the reversible inhibition of region-specific brain functions (Plaksin, Kimmel, \& Shoham, 2016), such as the suppression of visual evoked potential signals in rabbits (Yoo et al., 2011). The delivery of FUS to the thalamic area has also been shown to suppress electrographic seizure activity in a rodent model of acute epilepsy (Min et al., 2011). In a recent study in humans, the delivery of FUS to the primary somatosensory area suppressed electroencephalography signals elicited by the electric stimulation of the median nerve (Kim et al., 2015). Darrow et al. applied LIFUS to the thalamic ventral lateral nucleus in rodents after stimulating tibial nerve somatosensory evoked potentials (SSEPs) and found that LIFUS could reversibly inhibit SSEPs in a spatial and intensity-dependent manner while maintaining an independent duty ratio, peak pressure, or modulation frequency. Besides, similar thermal and inhibitory effects were produced by the transmission of three-dimensional guided heat signals through optical fibers; therefore, they concluded that the primary biophysical mechanism might be associated with the thermal effects of FUS treatment (Darrow, O'Brien, Richner, Netoff, \& Ebbini, 2019). Further studies remain necessary to dissect the mechanisms underlying the ability of TUS to stimulate various regions of the brain. Although the mechanisms underlying such effects have not yet been well-established, non-thermal and non-cavitational LIFUS is believed to excite neurons through the mechanical force of ultrasound intramembrane cavitation, which has been suggested to be a unifying mechanism for US-induced bioeffects(Chen, Wei, \& Liu, 2019; Krasovitski, Frenkel, Shoham, \& Kimmel, 2011; Kubanek, Shukla, Das, Baccus, \& Goodman, 2018; Plaksin et al., 2016). Many voltage-gated 
sodium, potassium, and calcium channels that influence neuronal excitability possess mechanically sensitive gating kinetics. The low-intensity US is significantly better at inducing $\mathrm{Ca}^{2+}$ influx and neuronal activationin vitro (Qiu et al., 2021). LIFUS-activated voltage-gated sodium channels induced vesicle exocytosis and synaptic transmission, further contributing to network activity (Tyler et al., 2008). The excitatory effects of LIFUS may also be modulated by the mechanical and stretch activation of voltage-gated $\mathrm{Na}^{+}$channels, resulting in neuronal depolarization and excitatory activity. The direct activation of ion channels by LIFUS may be one mechanism of action. At the molecular level, US stimulation appears to generate a transient, local gradient of cytokines, growth factors, and adhesion molecules (Liu et al., 2020). Neuromodulation by the low-intensity US might alter neuronal transmission and induce action potential changes through mechanical rather than thermal means. US-induced neuromodulation occurs via the mechanical stretch of the lipid bilayer (Gavrilov, Tsirulnikov, \& Davies, 1996). These voltage-gated channels typically transduce osmotic stress stimuli into ion fluxes and may be activated via LIFUS-induced mechanical stress (Boland \& Drzewiecki, 2008). At present, there are many explanations for the mechanism by which LIFUS can improve the motor symptoms of PD animals (Table 1; Fig 1), and there is still a long way to go to further clarify.

\section{LIFUS-mediated neuroprotection regulates dopamine mechanisms}

Wang (Wang et al., 2017) et al. demonstrated that ultrasound irradiation of MPTP model mice with the frequency of $1 \mathrm{MHz}$ and power of $0.3 \mathrm{~W} / \mathrm{cm}^{2}$ over $15 \mathrm{~min}$ for 10 days can improve the motor capacity and increase the DA content in the striatum. Zhou (Zhou, Niu, \& Meng et al., 2019) et al. used the MPTP mouse model of PD to demonstrate that noninvasive ultrasound deep brain stimulation (UDBS) of the STN or the globus pallidus (GP) improves motor behavior improved motor functioning and protected DA neurons through antiapoptotic effects. Based on these studies, we can conclude that US stimulation may effectively inhibit the loss of dopamine levels in brain tissue, improving the behavioral outcomes in mice. Even so, the specific mechanisms underlying these effects remain unclear. $\mathrm{Xu}$ and colleagues suggested that LIFUS-induced dopamine release can be attributed to the combination of neuronal regeneration and improved membrane permeability produced by the mechanical forces of US stimulation (Xu et al., 2020). Tests have shown that after 10 days of US treatments at an intensity of $0.3 \mathrm{~W} / \mathrm{cm}^{2}$, neuron repair occurred in the bilateral SN. The US stimulates the release of a range of biological macromolecules, and US contrast agents are used to create pores in cell membranes to improve transport during transient cavitation (Suarez, Jeremic, Cohen, \& Zderic, 2017). Recent research has suggested that intramembrane cavitation, also known as "bilayer sonophore," is the mechanism that that best explains the bioeffects observed in brain tissue following LIFUS administration at levels below Food and Drug Administration (FDA) imposed safety limits (Chen et al., 2019; Plaksin et al., 2016). According to this theory, bioeffects can vary from the delicate and reversible excitation of the cell membrane to pore formation and damage to membrane proteins or cytoskeletal fibers. Transient bilayer sonophore could modulate $\mathrm{Ca}^{2+}, \mathrm{K}^{+}$, and $\mathrm{Na}^{+}$influx and efflux, generating action potentials in the axons of neurons and increasing or suppressing neuronal activity (Blackmore, Shrivastava, Sallet, Butler, \& Cleveland, 2019; Kubanek et al., 2018). Therefore, LIFUS may directly promote the release of dopamine through these mechanisms, or it may facilitate the synthesis of dopamine and alleviate $\mathrm{PD}$ symptoms by promoting the recovery of dopaminergic neurons.

In summary, we can conclude that LIFUS applications result in direct therapeutic effects for PD and other neurodegenerative diseases through direct treatment of $\mathrm{PD}$, the enhancement of BDNF levels, the prevention of dopamine reduction, and the reduction of mitochondrial dysfunction and subsequent oxidative stress, and so on (Table 1; Fig 1). However, the detailed mechanisms through which LIFUS triggers these effects deserve further study.

\subsection{The mechanism through which LIFUS stimulation exerts a protective effect on oxidative damage}

$\mathrm{MPP}+$ is a dopaminergic neuronal toxin that is widely used to generate PD models in vitro. Whether LIFUS can protect dopaminergic neurons against MPP1-induced neurocytotoxicity remains unknown. Studies have shown that mitochondrial dysfunction and subsequent oxidative stress play central roles in the pathogenesis of PD(Javitch, D'Amato, Strittmatter, \& Snyder, 1985). In an MPP+-induced PC12 cell experiment, LIPUS stimulation can alleviate parkinsonian mimetic MPP1-induced neurotoxicity in PC12 cells and enhance nerve 
growth factor (NGF)-induced neurite outgrowth(Zhao et al., 2017). Furthermore, LIFUS stimulation was shown to suppress the MPP+-induced ROS generation and inhibition of mitochondrial complex I activity in an intensity-dependent manner at 30,50 , and $100 \mathrm{~mW} / \mathrm{cm}^{2}$, and $100 \mathrm{~mW} / \mathrm{cm}^{2}$ LIUS stimulation reversed the inhibitory effects of MPP + treatment on mitochondrial complex activity, resulting in the reduced phosphorylation and aggregation of $\alpha$-synuclein in PC12 cells(Karmacharya, Hada, Park, \& Choi, 2017). The functional activities of mitochondrial respiratory chain complexes are known to be affected by mechanical stress(Kindo et al., 2012). However, both non-thermal and non-cavitational LIFUS is believed to excite neurons through mechanical force, and US intramembrane cavitation has been suggested as a potentially unifying mechanism that might explain various US-induced bioeffects(Chen et al., 2019; Krasovitski et al., 2011; Plaksin et al., 2016).

\section{The effects and mechanism of theLIFUS-mediated permeabilization of the BBB in PD}

The BBB presents a major challenge for the delivery of therapeutic agents to the brain. LIFUS as a tool for increasing BBB permeability could provide a new, reversible approach to the treatment of several pathologies, such as brain tumors, degenerative diseases, and thrombosis. FUS can temporarily permeabilize the BBB and promote the penetrance of putative neuroprotectants, providing an interesting prospect (Karakatsani, Blesa, \& Konofagou, 2019).

The PD lesion site is focal, and the opening of the BBB mediated by LIFUS for early intervention of the diseased site is an important breakthrough in PD research. A single intravenous injection of AAV9 encoding alpha-syn inhibitory RNA and delivering it to the brain in combination with microvesicles was sufficient to reduce the expression of alpha-syn in transgenic mice expressing human alpha-synuclein in FUS-targeted brain regions (Xhima, Nabbouh, Hynynen, Aubert, \& Tandon, 2018). This study suggests that the ability of gene therapy to target specific brain regions may prevent the spread of Lewy bodies after $\alpha$-SYN knockout, which could improve early diagnosis as prodromal PD markers. In a subacute MPTP mouse model of early PD, Karakatsani et al. reduced damage to the substantia nigra striatum dopaminergic pathway by allowing these drugs to enter the brain parenchyma by using FUS combined with microvesicle injection of neurotrophic factors (delivered via proteins or genes) (Karakatsani et al., 2019). The US-mediated delivery of immune-related genes or antigens could be used to enhance immune responses, and also with positive effects on the lesion area (Shi, Zhong, Ye, \& Zhang, 2019). In the early stage of PD, FUS can deliver drugs to appropriate brain regions and promote the delivery of key neurotrophic factors to improve the function of neurons and inhibit neurodegenerative lesions, providing a new idea for the early treatment of CNS disease.

Microbubbles and nanoparticles (NPs) are commonly used as gene and drug carriers. Research has underlined that LIFUS can be applied to activate stable microbubble oscillations, triggering the release of drugs from nanoparticles (Wang et al., 2020). Although these effects can vary greatly depending on the purpose, the PD model being used, the selected nanoparticle injection mechanism, the delivery vehicle, and the nanoparticle contents. For example, GDNF can be delivered to MPTP mice or 6-OHDA rats using adeno-associated virus, gene-liposome-microbubbles, brain-penetrating nanoparticles, and cationic microbubbles administered intravenously (Fan, Lin, Liu, \& Yeh, 2017; Karakatsani et al., 2019; Lin et al., 2016; Mead et al., 2017). These genus-based models (MPTP and 6-OHDA) are typically used to study the causes of dopamine loss in the neurons of the SN pars compacta and the striatum. To modulate $\alpha$-synuclein aggregation in the brain, A53T $\alpha$-syn mice and wild-type $\alpha$-syn mice can be used (Wang et al., 2017; Xhima et al., 2018). Different types of animal models respond differently to the injection of varying molecular weight compounds, such as anti-syn antibody (Xhima et al., 2018), neurturin (Karakatsani et al., 2019) and Nrf2(Long et al., 2017) into the brain parenchym (Table 2; Fig 1).

$\mathrm{NP}_{\mathrm{S}}$ is effective in treating Parkinson's disease in vivo and in vitro by carrying a variety of therapeutic agents. Gold nanoparticles (GNP) inhibit the apoptosis of PC12 cells and dopaminergic neurons through endocytosis of transfected cells and can also successfully pass through the BBB in MPTP animal models (Hu et al., 2018). Gelatin NPs loaded with neuropeptide P (SP-GNP) significantly increased the number of dopaminergic neurons and reduced glial cell proliferation, inflammatory cell infiltration, and connective tissue proliferation in PD model rats (Zhao et al., 2016). GDNF genes packaged in angiopep-2-modified 
NPs were able to improve motor dysfunction and restore dopaminergic neurons (Huang et al., 2013). The locomotor function is markedly improved in 6-OHDA lesioned rats that subsequently received FUS-Targeted GDNF-brain penetrating nanoparticles(BPN)delivery with FUS(Mead et al., 2017). The combination of FUS and NPs has resulted in a good response during glioma treatment in other fields (Li et al., 2018), however, few experimental studies have been performed on the combination of LIFUS and Ns in PD, which is worthy of further research.

FUS combined microvesicles have been used as an effective and safe method for non-invasive, local and transient BBB opening. Rich et al. demonstrated that intravenous nanoclusters could be deposited into targeted brain regions via FUS-facilitated BBB permeabilization (Rich et al., 2020). In a rhesus monkey animal model (a microbubble dose of $20 \mu \mathrm{l} / \mathrm{kg}$, a total US duration of $150 \mathrm{~s}$, pulsed waves of $10 \mathrm{~ms}$ and $1 \mathrm{~Hz}$ for 70 seconds), BBB permeabilization can occur repeatedly and reliably without causing significant histological or functional impairment (Mcdannold, Arvanitis, Vykhodtseva, \& Livingstone, 2012). MRI-guided FUS was used to enhance the delivery of polyethylene glycol (PEG)ylated liposome-coupled microbubbles for the gene transfer of glial cell line-derived neurotrophic factor (GDNF)-encoding plasmids (PLs-GDNF-MBs) in the brain, which alleviated behavioral deficits and neuron loss in a rat model of PD established by a unilateral 6-hydroxydopamine (6-OHDA) lesion (Yue, Miao, Gao, Zhao, \& Teng, 2018). Ultrasoundtargeted microbubble destruction (UTMD) in conjunction with neurotrophic factors (NFs) gene delivery has the potential to facilitate successful gene transduction in dopaminergic neurons to recover normal secretion of DA (and metabolites), along with a neuroprotective effect and the restoration of PD-model motor behavior (Lin et al., 2020). In another study, the results indicated that FUS-induced BBB permeabilization, in conjunction with microbubble delivery, enhanced neurturin transport and triggered the neuroregeneration cascade in the nigrostriatal pathway, which could be detected downstream of the neuronal nuclei (Samiotaki, Acosta, Wang, \& Konofagou, 2015). How does FUS combine with microbubbles to open the BBB? When the FUS wave is activated, the microbubbles with a diameter of 1-4 $\mu \mathrm{m}$ expand and contract, known as acoustic cavitation. The oscillating microbubbles stretch on the walls of blood vessels and produce fluid shear stress and circumferential stress on the capillary wall (Burgess \& Hynynen, 2013). The mechanical force generated by microbubbles on the blood vessel wall for the opening of the BBB also causes the expansion and contraction of the space around the blood vessel, which is called the microbubble pump effect (Chen, Kreider, Brayman, Bailey, \& Matula, 2011). These stresses disrupt the tight connections in the wall, triggering an active transport process and creating a brief window during which the drug or gene can be transported across the BBB (Price et al., 2019). Another study showed that the combination of LIFUS and encapsulated microvesicles can change the permeability of cell membrane, and the overstretched cell membrane leads to the formation of repairable submicron pores, which provides preliminary evidence for the mechanism of ultrasonic opening of low-amplitude ultrasound (Nejad, Hosseini, Akiyama, \& Tachibana, 2016). There are still many questions about the mechanism of focusing ultrasound to open the BBB. However, focused ultrasound to open BBB may open a new avenue for the treatment of Parkinson's disease.

\section{Safety of LIFUS}

Multimodal analysis studies have indicated that therapeutic US is a safe method of BBB permeabilization and may potentially be protective in the long term, underscoring the validity of the US as a potential treatment modality for diseases of the brain(Blackmore et al., 2018). In sharp contrast with HIFU, none of the studies using LIFUS have indicated any problems associated with histological, BBB, or behavioral outcomes (Bystritsky et al., 2011). Studies have shown that FUS can permeabilize the BBB at the level of the caudate nucleus and the putamen of anesthetized primates while monitoring the safety by examining vital signs, physiological changes, MRI analysis, and behavioral testing. No significant physiological or major vital sign variations were reported, and no evidence of hemorrhage was identified on MRI(Bowary \& Greenberg, 2018). Furthermore, continuous TUS stimulation has been used for decades to perform echoencephalography without safety concerns. Various US applications represent promising and potentially powerful neurostimulation tools, which are effective for neuromodulation in monkeys (Durand et al., 2015) and even humans(Lee et al., 2015). The safety of MRI-guided FUS also allows for repeated treatments, and the duration and spatial properties of the BBB opening can be adjusted by changing the ultrasound parameters and the microbubble size and 
dose, allowing for a variety of therapeutic drugs to be delivered to targets(Meng et al., 2018). The FDA has established guidelines regarding the maximum allowable US parameters for diagnostic purposes. These regulations cover the thermal index (level of heating), the mechanical index (level of mechanical effects), the spatial peak temporal average intensity (Ispta), and the spatial peak pulse average intensity (Isppa) (Yuan et al., 2020). Previous studies have shown that changes in US parameters can cause different modulatory effects on neural activity (Ye, Brown, \& Pauly, 2016). The application of US parameters below FDA limits has the potential for use as a novel and as a potential non-invasive treatment option for PD patients who may be reluctant to undergo conventional surgeries or may be poor candidates for such treatments. Lee et al. stimulated the primary visual cortex in humans without causing tissue damage using energy doses above the established FDA limits, underscoring the safety of LIFUS and the importance of performing future research to establish precise safety parameters (Lee et al., 2016). To identify the optimal parameters for PD neuromodulation, we will conduct a multiparameter study to determine which US parameters have the best therapeutic effects. However, as with any emerging technology, long-term, longitudinal safety studies remain necessary, examining a broad set of parameters, such as frequency, intensity, US time, and DC.

\section{Limitations of LIFUS}

In clinical applications, FUS has non-invasive merit; however, US energy can be attenuated by the skull, resulting in differences in energy efficiency among patients. Lower ratios of cancellous bone to cortical bone are associated with the increased attenuation of US energy. As the density of cancellous bone decreases, the attenuation rate of US energy also decreases (Kong et al., 2019). In their study, correlations between skull components and US energy were obtained through the use of 3D printing, allowing the optimal US parameters necessary for clinical research to be established by comparisons with actual skull components. Neurons rely on changes in the membrane's electrical potential to send and receive messages. Bilayer sonophore membrane effects vary with frequency, and the neuronal intramembrane cavitation excitation model suggests that these frequency differences vary according to cell type (Plaksin et al., 2016). The bilayer sonophore simulation model showed that bioeffects on the cell membrane depended on variations in the US parameters as well as the maximum area strain-absorbing ability of the membrane leaflets (Babakhanian et al., 2018). Despite these recent successes, gaps in our knowledge regarding the mechanisms underlying in vivo US stimulation and the best US spatial-temporal parameters for inducing such stimulation remain. Different acoustic parameters can induce a variety of biological effects, depending on the cell type and tissue structure (King, Brown, Newsome, \& Pauly, 2013).

LIFUS is an emerging form of neuromodulation, but its sheer size limits its use in wearables and prevents its integration with other experimental models. The Fiber Optoacoustic Converter (FOC), which has a diameter of $600 \mu \mathrm{m}$, can generate omnidirectional, local US waves at the fiber tip by utilizing the photoacoustic effect. The sound waves generated by FOC can directly activate a single cultured neuron and generate intracellular $\mathrm{Ca}^{2+}$ influx. The use of transient FOC to activate neurons within a radius of $500 \mu \mathrm{m}$ surrounding the fiber tip can provide better spatial resolution than traditional piezoelectric, low-frequency sensors (Blackmore et al., 2019).

The variability observed among studies and the limited success may be the result of the lack of answers for the following questions. 1. Through what mechanism does US stimulation improve motor symptoms in PD animal models? 2. How does LIFUS affect neural regulation, what relationships exist between these mechanisms, and how does bidirectional regulation produce neuronal excitation or inhibition in response to US parameters? 3. What range of US parameters should be applied to different patients with different degrees of disease, and how can the US be limited in size to specific regions of brain tissue to ensure the safety of US applications?

\section{Conclusion}

This review summarizes the roles and mechanisms of LIFUS in the treatment of PD and describes stimulation principles, safety, and limitations of LIFUS. Clinical studies on the benefits of LIFUS for drug delivery in PD patients have not yet been performed, although preclinical studies have shown promising early results. We 
look forward to exploring the further clinical application of LIFUS in the field of neurodegenerative disease research and further developing this treatment approach.

\section{Conflict of Interest}

The authors declare that the research was conducted in the absence of any commercial or financial relationships that could be construed as a potential conflict of interest.

\section{Acknowledgements}

This work was supported by the Natural Science Foundation of Guangdong Province (2018A0303130307), a grant from the Guangdong Basic and Applied Basic Research Foundation (2019A1515011739), and a grant from the Fundamental Research Funds for the Central Universities (19ykpy27).

\section{References}

Babakhanian, M., Yang, L., Nowroozi, B., Saddik, G., Boodaghians, L., \& Blount, P., et al. (2018). Effects of Low Intensity Focused Ultrasound on Liposomes Containing Channel proteins. Sci Rep , 8 (1), 17250. http://doi.org/10.1038/s41598-018-35486-1.

Baek, H., Pahk, K. J., \& Kim, H. (2017). A review of low-intensity focused ultrasound for neuromodulation. Biomed Eng Lett ,7 (2), 135-142. http://doi.org/10.1007/s13534-016-0007-y.

Bauer, R., Martin, E., Haegele-Link, S., Kaegi, G., von Specht, M., \& Werner, B. (2014). Noninvasive functional neurosurgery using transcranial MR imaging-guided focused ultrasound. Parkinsonism Relat Disord , 20 Suppl 1 , S197-S199. http://doi.org/10.1016/S1353-8020(13)70046-4.

Blackmore, D. G., Turpin, F., Mohamed, A. Z., Zong, F., Pandit, R., \& Pelekanos, M., et al. (2018). Multimodal analysis of aged wild-type mice exposed to repeated scanning ultrasound treatments demonstrates long-term safety. Theranostics , 8 (22), 6233-6247. http://doi.org/10.7150/thno.27941.

Blackmore, J., Shrivastava, S., Sallet, J., Butler, C. R., \& Cleveland, R. O. (2019). Ultrasound Neuromodulation: A Review of Results, Mechanisms and Safety. Ultrasound in Medicine and Biology , 45 (7), 1509-1536. http://doi.org/10.1016/j.ultrasmedbio.2018.12.015.

Boland, L. M., \& Drzewiecki, M. M. (2008). Polyunsaturated fatty acid modulation of voltage-gated ion channels. Cell Biochemistry and Biophysics , 52 (2), 59-84. http://doi.org/10.1007/s12013-008-9027-2.

Bowary, P., \& Greenberg, B. D. (2018). Noninvasive Focused Ultrasound for Neuromodulation: A Review. Psychiatr Clin North Am ,41 (3), 505-514. http://doi.org/10.1016/j.psc.2018.04.010.

Burgess, A., \& Hynynen, K. (2013). Noninvasive and targeted drug delivery to the brain using focused ultrasound. Acs Chemical Neuroscience , 4 (4), 519-526. http://doi.org/10.1021/cn300191b.

Bystritsky, A., Korb, A. S., Douglas, P. K., Cohen, M. S., Melega, W. P., \& Mulgaonkar, A. P., et al. (2011). A review of low-intensity focused ultrasound pulsation. Brain Stimulation , 4 (3), 125-136. http://doi.org/10.1016/j.brs.2011.03.007.

Chang, C. J., Hsu, S. H., Lin, F. T., Chang, H., \& Chang, C. S. (2005). Low-intensity-ultrasound-accelerated nerve regeneration using cell-seeded poly(D,L-lactic acid-co-glycolic acid) conduits: an in vivo and in vitro study. J Biomed Mater Res B Appl Biomater ,75 (1), 99-107. http://doi.org/10.1002/jbm.b.30269.

Chen, H., Kreider, W., Brayman, A. A., Bailey, M. R., \& Matula, T. J. (2011). Blood vessel deformations on microsecond time scales by ultrasonic cavitation. Physical Review Letters , 106 (3), 34301. http://doi.org/10.1103/PhysRevLett.106.034301.

Chen, K. T., Wei, K. C., \& Liu, H. L. (2019). Theranostic Strategy of Focused Ultrasound Induced Blood-Brain Barrier Opening for CNS Disease Treatment. Frontiers in Pharmacology , 10 , 86. http://doi.org/10.3389/fphar.2019.00086. 
Connolly, B. S., \& Lang, A. E. (2014). Pharmacological treatment of Parkinson disease: a review. JAMA , 311 (16), 1670-1683. http://doi.org/10.1001/jama.2014.3654.

Dallapiazza, R. F., Timbie, K. F., Holmberg, S., Gatesman, J., Lopes, M. B., \& Price, R. J., et al. (2018). Noninvasive neuromodulation and thalamic mapping with low-intensity focused ultrasound. Journal of Neurosurgery , 128 (3), 875-884. http://doi.org/10.3171/2016.11.JNS16976.

Darrow, D. P., O’Brien, P., Richner, T. J., Netoff, T. I., \& Ebbini, E. S. (2019). Reversible neuroinhibition by focused ultrasound is mediated by a thermal mechanism. Brain Stimulation , 12 (6), 1439-1447. http://doi.org/10.1016/j.brs.2019.07.015.

di Biase, L., Falato, E., \& Di Lazzaro, V. (2019). Transcranial Focused Ultrasound (tFUS) and Transcranial Unfocused Ultrasound (tUS) Neuromodulation: From Theoretical Principles to Stimulation Practices.Frontiers in Neurology , 10 , 549. http://doi.org/10.3389/fneur.2019.00549.

Durand, E., Petit, O., Tremblay, L., Zimmer, C., Sgambato-Faure, V., \& Chassain, C., et al. (2015). Social behavioral changes in MPTP-treated monkey model of Parkinson's disease. Frontiers in Behavioral Neuroscience, 9 , 42. http://doi.org/10.3389/fnbeh.2015.00042.

Ellis, J. M., \& Fell, M. J. (2017). Current approaches to the treatment of Parkinson's Disease. Bioorganic E Medicinal Chemistry Letters , 27 (18), 4247-4255. http://doi.org/10.1016/j.bmcl.2017.07.075.

Fabbri, M., Zibetti, M., Calandra-Buonaura, G., Contin, M., Sambati, L., \& Mohamed, S., et al. (2020). Levodopa/Carbidopa Intestinal Gel Long-Term Outcome in Parkinson's Disease: Focus on Dyskinesia. Mov Disord Clin Pract , 7 (8), 930-939. http://doi.org/10.1002/mdc3.13068.

Fan, C. H., Lin, C. Y., Liu, H. L., \& Yeh, C. K. (2017). Ultrasound targeted CNS gene delivery for Parkinson's disease treatment. Journal of Controlled Release , 261 , 246-262. http:// doi.org/10.1016/j.jconrel.2017.07.004.

Fry, W. J., Barnard, J. W., Fry, E. J., Krumins, R. F., \& Brennan, J. F. (1955). Ultrasonic lesions in the mammalian central nervous system.Science , 122 (3168), 517-518.

Gavrilov, L. R., Tsirulnikov, E. M., \& Davies, I. A. (1996). Application of focused ultrasound for the stimulation of neural structures. Ultrasound in Medicine and Biology ,22 (2), 179-192. http://doi.org/10.1016/0301$5629(96) 83782-3$.

Hu, K., Chen, X., Chen, W., Zhang, L., Li, J., \& Ye, J., et al. (2018). Neuroprotective effect of gold nanoparticles composites in Parkinson's disease model. Nanomedicine , 14 (4), 1123-1136. http://doi.org/10.1016/j.nano.2018.01.020.

Huang, R., Ma, H., Guo, Y., Liu, S., Kuang, Y., \& Shao, K., et al. (2013). Angiopep-conjugated nanoparticles for targeted long-term gene therapy of Parkinson's disease. Pharm Res , 30 (10), 2549-2559. http://doi.org/10.1007/s11095-013-1005-8.

Javitch, J. A., D’Amato, R. J., Strittmatter, S. M., \& Snyder, S. H. (1985). Parkinsonism-inducing neurotoxin, N-methyl-4-phenyl-1,2,3,6 -tetrahydropyridine: uptake of the metabolite N-methyl-4-phenylpyridine by dopamine neurons explains selective toxicity. Proc Natl Acad Sci U A , 82 (7), 2173-2177. http://doi.org/10.1073/pnas.82.7.2173.

Jiang, W., Wang, Y., Tang, J., Peng, J., Wang, Y., \& Guo, Q., et al. (2016). Low-intensity pulsed ultrasound treatment improved the rate of autograft peripheral nerve regeneration in rat. Sci Rep ,6 , 22773. http://doi.org/10.1038/srep22773.

Karakatsani, M. E., Blesa, J., \& Konofagou, E. E. (2019). Blood-brain barrier opening with focused ultrasound in experimental models of Parkinson's disease. Mov Disord , 34 (9), 1252-1261. http://doi.org/10.1002/mds.27804. 
Karakatsani, M. E., Wang, S., Samiotaki, G., Kugelman, T., Olumolade, O. O., \& Acosta, C., et al. (2019). Amelioration of the nigrostriatal pathway facilitated by ultrasound-mediated neurotrophic delivery in early Parkinson's disease. Journal of Controlled Release ,303 , 289-301. http://doi.org/10.1016/j.jconrel.2019.03.030.

Karmacharya, M. B., Hada, B., Park, S. R., \& Choi, B. H. (2017). Low-Intensity Ultrasound Decreases $\alpha-$ Synuclein Aggregation via Attenuation of Mitochondrial Reactive Oxygen Species in MPP(+)-Treated PC12 Cells. Molecular Neurobiology , 54 (8), 6235-6244. http://doi.org/10.1007/s12035-016-0104-z.

Karmacharya, M. B., Kim, K. H., Kim, S. Y., Chung, J., Min, B. H., \& Park, S. R., et al. (2015). Low intensity ultrasound inhibits brain oedema formation in rats: potential action on AQP4 membrane localization. Neuropathol Appl Neurobiol , 41 (4), e80-e94. http://doi.org/10.1111/nan.12182.

Kim, H., Park, M. Y., Lee, S. D., Lee, W., Chiu, A., \& Yoo, S. S. (2015). Suppression of EEG visualevoked potentials in rats through neuromodulatory focused ultrasound. Neuroreport , 26 (4), 211-215. http://doi.org/10.1097/WNR.0000000000000330.

Kindo, M., Gerelli, S., Bouitbir, J., Charles, A. L., Zoll, J., \& Hoang, M. T., et al. (2012). Pressure overload-induced mild cardiac hypertrophy reduces left ventricular transmural differences in mitochondrial respiratory chain activity and increases oxidative stress.Frontiers in Physiology , 3 , 332. http://doi.org/10.3389/fphys.2012.00332.

King, R. L., Brown, J. R., Newsome, W. T., \& Pauly, K. B. (2013). Effective parameters for ultrasound-induced in vivo neurostimulation.Ultrasound in Medicine and Biology , 39 (2), 312-331. http://doi.org/10.1016/j.ultrasmedbio.2012.09.009.

Kong, C., Shin, J., Na, Y. C., Park, J., Baek, H. G., \& Chang, J. W., et al. (2019). Optimization of intracranial penetration of focused ultrasound through energy efficiency analysis of various skull factors.IBRO Reports , 6 , S168. http://doi.org/10.1016/j.ibror.2019.07.530.

Krasovitski, B., Frenkel, V., Shoham, S., \& Kimmel, E. (2011). Intramembrane cavitation as a unifying mechanism for ultrasound-induced bioeffects. Proc Natl Acad Sci U S A , 108 (8), 3258-3263. http://doi.org/10.1073/pnas.1015771108.

Krishna, V., Sammartino, F., \& Rezai, A. (2018). A Review of the Current Therapies, Challenges, and Future Directions of Transcranial Focused Ultrasound Technology: Advances in Diagnosis and Treatment. Jama Neurology , 75 (2), 246-254. http://doi.org/10.1001/jamaneurol.2017.3129.

Kubanek, J., Brown, J., Ye, P., Pauly, K. B., Moore, T., \& Newsome, W. (2020). Remote, brain region-specific control of choice behavior with ultrasonic waves. Science Advances , 6 (21), z4193. http://doi.org/10.1126/sciadv.aaz4193.

Kubanek, J., Shukla, P., Das, A., Baccus, S. A., \& Goodman, M. B. (2018). Ultrasound Elicits Behavioral Responses through Mechanical Effects on Neurons and Ion Channels in a Simple Nervous System. Journal of Neuroscience , 38 (12), 3081-3091. http://doi.org/10.1523/JNEUROSCI.1458-17.2018.

Lee, E. J., Fomenko, A., \& Lozano, A. M. (2019). Magnetic Resonance-Guided Focused Ultrasound: Current Status and Future Perspectives in Thermal Ablation and Blood-Brain Barrier Opening. J Korean Neurosurg Soc ,62 (1), 10-26. http://doi.org/10.3340/jkns.2018.0180.

Lee, W., Kim, H. C., Jung, Y., Chung, Y. A., Song, I. U., \& Lee, J. H., et al. (2016). Transcranial focused ultrasound stimulation of human primary visual cortex. Sci Rep , 6 , 34026. http:// doi.org/10.1038/srep34026.

Lee, W., Kim, H., Jung, Y., Song, I. U., Chung, Y. A., \& Yoo, S. S. (2015). Image-guided transcranial focused ultrasound stimulates human primary somatosensory cortex. Sci Rep , 5 , 8743. http:// doi.org/10.1038/srep08743. 
Lewitt, P. A., Lipsman, N., \& Kordower, J. H. (2019). Focused ultrasound opening of the blood-brain barrier for treatment of Parkinson's disease. Mov Disord , 34 (9), 1274-1278. http://doi.org/10.1002/mds.27722.

Li, Q., Ke, Y., Chan, D. C., Qian, Z. M., Yung, K. K., \& Ko, H., et al. (2012). Therapeutic deep brain stimulation in Parkinsonian rats directly influences motor cortex. Neuron , 76 (5), 1030-1041. http://doi.org/10.1016/j.neuron.2012.09.032.

Li, Y., Wu, M., Zhang, N., Tang, C., Jiang, P., \& Liu, X., et al. (2018). Mechanisms of enhanced antiglioma efficacy of polysorbate 80-modified paclitaxel-loaded PLGA nanoparticles by focused ultrasound.Journal of Cellular and Molecular Medicine, 22 (9), 4171-4182. http:// doi .org/10.1111/jcmm.13695.

Lin, C. Y., Hsieh, H. Y., Chen, C. M., Wu, S. R., Tsai, C. H., \& Huang, C. Y., et al. (2016). Non-invasive, neuron-specific gene therapy by focused ultrasound-induced blood-brain barrier opening in Parkinson's disease mouse model. Journal of Controlled Release, 235 , 72-81. http://doi.org/10.1016/j.jconrel.2016.05.052.

Lin, C. Y., Lin, Y. C., Huang, C. Y., Wu, S. R., Chen, C. M., \& Liu, H. L. (2020). Ultrasound-responsive neurotrophic factor-loaded microbubble- liposome complex: Preclinical investigation for Parkinson's disease treatment. Journal of Controlled Release, 321 , 519-528. http:// doi.org/10.1016/j.jconrel.2020.02.044.

Lin, W. T., Chen, R. C., Lu, W. W., Liu, S. H., \& Yang, F. Y. (2015). Protective effects of low-intensity pulsed ultrasound on aluminum-induced cerebral damage in Alzheimer's disease rat model.Sci Rep , 5 , 9671. http://doi.org/10.1038/srep09671.

Lipsman, N., Schwartz, M. L., Huang, Y., Lee, L., Sankar, T., \& Chapman, M., et al. (2013). MR-guided focused ultrasound thalamotomy for essential tremor: a proof-of-concept study. Lancet Neurology ,12 (5), 462-468. http://doi.org/10.1016/S1474-4422(13)70048-6.

Liu, D. D., Ullah, M., Concepcion, W., Dahl, J. J., \& Thakor, A. S. (2020). The role of ultrasound in enhancing mesenchymal stromal cell-based therapies. Stem Cells Transl Med , 9 (8), 850-866. http://doi.org/10.1002/sctm.19-0391.

Liu, S. H., Lai, Y. L., Chen, B. L., \& Yang, F. Y. (2017). Ultrasound Enhances the Expression of BrainDerived Neurotrophic Factor in Astrocyte Through Activation of TrkB-Akt and Calcium-CaMK Signaling Pathways. Cerebral Cortex, 27 (6), 3152-3160. http://doi.org/10.1093/cercor/bhw169.

Long, L., Cai, X., Guo, R., Wang, P., Wu, L., \& Yin, T., et al. (2017). Treatment of Parkinson's disease in rats by Nrf2 transfection using MRI-guided focused ultrasound delivery of nanomicrobubbles.Biochem Biophys Res Commun , 482 (1), 75-80. http://doi.org/10.1016/j.bbrc.2016.10.141.

Mcdannold, N., Arvanitis, C. D., Vykhodtseva, N., \& Livingstone, M. S. (2012). Temporary disruption of the blood-brain barrier by use of ultrasound and microbubbles: safety and efficacy evaluation in rhesus macaques. Cancer Research, 72 (14), 3652-3663. http://doi.org/10.1158/0008-5472.CAN-12-0128.

Mead, B. P., Kim, N., Miller, G. W., Hodges, D., Mastorakos, P., \& Klibanov, A. L., et al. (2017). Novel Focused Ultrasound Gene Therapy Approach Noninvasively Restores Dopaminergic Neuron Function in a Rat Parkinson's Disease Model. Nano Letters , 17 (6), 3533-3542. http://doi.org/10.1021/acs.nanolett.7b00616.

Meng, Y., Voisin, M. R., Suppiah, S., Kalia, S. K., Kalia, L. V., \& Hamani, C., et al. (2018). Is there a role for MR-guided focused ultrasound in Parkinson's disease? Mov Disord , 33 (4), 575-579. http://doi.org/10.1002/mds.27308.

Meng, Y., Volpini, M., Black, S., Lozano, A. M., Hynynen, K., \& Lipsman, N. (2017). Focused ultrasound as a novel strategy for Alzheimer disease therapeutics. Annals of Neurology , 81 (5), 611-617. http://doi.org/10.1002/ana.24933.

Min, B. K., Bystritsky, A., Jung, K. I., Fischer, K., Zhang, Y., \& Maeng, L. S., et al. (2011). Focused ultrasound-mediated suppression of chemically-induced acute epileptic EEG activity. Bmc Neuroscience, 12 , 23. http://doi.org/10.1186/1471-2202-12-23. 
Miocinovic, S., Ostrem, J. L., Okun, M. S., Bullinger, K. L., Riva-Posse, P., \& Gross, R. E., et al. (2020). Recommendations for Deep Brain Stimulation Device Management During a Pandemic. J Parkinsons Dis , 10 (3), 903-910. http://doi.org/10.3233/JPD-202072.

Nejad, S. M., Hosseini, H., Akiyama, H., \& Tachibana, K. (2016). Reparable Cell Sonoporation in Suspension: Theranostic Potential of Microbubble.Theranostics , 6 (4), 446-455. http:// doi .org/10.7150/thno.13518.

Panczykowski, D. M., Monaco, E. R., \& Friedlander, R. M. (2014). Transcranial focused ultrasound modulates the activity of primary somatosensory cortex in humans. Neurosurgery , 74 (6), N8. http://doi.org/10.1227/NEU.000000000000365.

Plaksin, M., Kimmel, E., \& Shoham, S. (2016). Cell-Type-Selective Effects of Intramembrane Cavitation as a Unifying Theoretical Framework for Ultrasonic Neuromodulation. eNeuro , 3 (3). http://doi.org/10.1523/ENEURO.0136-15.2016.

Price, R. J., Fisher, D. G., Suk, J. S., Hanes, J., Ko, H. S., \& Kordower, J. H. (2019). Parkinson's disease gene therapy: Will focused ultrasound and nanovectors be the next frontier? Mov Disord ,34 (9), 1279-1282. http://doi.org/10.1002/mds.27675.

Qian, H., Kang, X., Hu, J., Zhang, D., Liang, Z., \& Meng, F., et al. (2020). Reversing a model of Parkinson's disease with in situ converted nigral neurons. Nature, 582 (7813), 550-556. http://doi.org/10.1038/s41586020-2388-4.

Qiu, Z., Kala, S., Guo, J., Xian, Q., Zhu, J., \& Zhu, T., et al. (2021). Targeted Neurostimulation in Mouse Brains with Non-invasive Ultrasound.Cell Reports , 34 (1), 108595. http://doi.org/10.10 16/j.celrep.2020.108595.

Rich, M. C., Sherwood, J., Bartley, A. F., Whitsitt, Q. A., Lee, M., \& Willoughby, W. R., et al. (2020). Focused ultrasound blood brain barrier opening mediated delivery of MRI-visible albumin nanoclusters to the rat brain for localized drug delivery with temporal control. Journal of Controlled Release, 324, 172-180. http://doi.org/10.1016/j.jconrel.2020.04.054.

Samiotaki, G., Acosta, C., Wang, S., \& Konofagou, E. E. (2015). Enhanced delivery and bioactivity of the neurturin neurotrophic factor through focused ultrasound-mediated blood-brain barrier opening in vivo. $J$ Cereb Blood Flow Metab , 35 (4), 611-622. http://doi.org/10.1038/jcbfm.2014.236.

Scarcelli, T., Jordão, J. F., O’Reilly, M. A., Ellens, N., Hynynen, K., \& Aubert, I. (2014). Stimulation of hippocampal neurogenesis by transcranial focused ultrasound and microbubbles in adult mice.Brain Stimulation , 7 (2), 304-307. http://doi.org/10.1016/j.brs.2013.12.012.

Shi, G., Zhong, M., Ye, F., \& Zhang, X. (2019). Low-frequency HIFU induced cancer immunotherapy: tempting challenges and potential opportunities.Cancer Biology \& Medicine , 16 (4), 714-728. http://doi.org/10.20892/j.issn.2095-3941.2019.0232.

Son, S., Kim, J. H., Wang, X., Zhang, C., Yoon, S. A., \& Shin, J., et al. (2020). Multifunctional sonosensitizers in sonodynamic cancer therapy. Chemical Society Reviews , 49 (11), 3244-3261. http://doi.org/10.1039/c9cs00648f.

Suarez, C. I., Jeremic, A., Cohen, J., \& Zderic, V. (2017). Ultrasound Stimulation of Insulin Release from Pancreatic Beta Cells as a Potential Novel Treatment for Type 2 Diabetes. Ultrasound in Medicine and Biology , 43 (6), 1210-1222. http://doi.org/10.1016/j.ultrasmedbio.2017.01.007.

Trist, B. G., Hare, D. J., \& Double, K. L. (2019). Oxidative stress in the aging substantia nigra and the etiology of Parkinson's disease.Aging Cell , 18 (6), e13031. http://doi.org/10.1111/acel.13031.

Tufail, Y., Matyushov, A., Baldwin, N., Tauchmann, M. L., Georges, J., \& Yoshihiro, A., et al. (2010). Transcranial pulsed ultrasound stimulates intact brain circuits. Neuron , 66 (5), 681-694. 
http://doi.org/10.1016/j.neuron.2010.05.008.

Tyler, W. J., Tufail, Y., Finsterwald, M., Tauchmann, M. L., Olson, E. J., \& Majestic, C. (2008). Remote excitation of neuronal circuits using low-intensity, low-frequency ultrasound. Plos One , 3 (10), e3511. http://doi.org/10.1371/journal.pone.0003511.

Wang, S., Guo, X., Ren, L., Wang, B., Hou, L., \& Zhou, H., et al. (2020). Targeting and deep-penetrating delivery strategy for stented coronary artery by magnetic guidance and ultrasound stimulation. Ultrasonics Sonochemistry , 67 , 105188. http://doi.org/10.1016/j.ultsonch.2020.105188.

Wang, W., Li, L., Wu, W., Zhang, W., Gao, Y., \& Chen, C. (2017). Effects of Ultrasound on Behavior and Dopamine Content in Striatum of Parkinson's Disease Model Mouse. In J. Xiao, G. Ke, \& S. Lunev (Eds.),AER-Advances in Engineering Research (pp. 186-191).

Xhima, K., Nabbouh, F., Hynynen, K., Aubert, I., \& Tandon, A. (2018). Noninvasive delivery of an $\alpha-$ synuclein gene silencing vector with magnetic resonance-guided focused ultrasound. Mov Disord ,33 (10), 1567-1579. http://doi.org/10.1002/mds.101.

Xie, J., Shen, Z., Anraku, Y., Kataoka, K., \& Chen, X. (2019). Nanomaterial-based blood-brain-barrier (BBB) crossing strategies.Biomaterials ,224 , 119491. http://doi.org/10.1016/j.bioma-terials.2019.119491.

Xu, T., Lu, X., Peng, D., Wang, G., Chen, C., \& Liu, W., et al. (2020). Ultrasonic stimulation of the brain to enhance the release of dopamine - A potential novel treatment for Parkinson's disease. Ultrasonics Sonochemistry , 63 , 104955. http://doi.org/10.1016/j.ultsonch.2019.104955.

Yang, A., Qiao, B., Strohm, E. M., Cao, J., Wang, Z., \& Yuan, X., et al. (2020). Thrombin-responsive engineered nanoexcavator with full-thickness infiltration capability for pharmaceutical-free deep venous thrombosis theranostics. Biomater Sci , 8 (16), 4545-4558. http://doi.org/ 10.1039/d0bm00917b.

Yang, F. Y., Lu, W. W., Lin, W. T., Chang, C. W., \& Huang, S. L. (2015). Enhancement of Neurotrophic Factors in Astrocyte for Neuroprotective Effects in Brain Disorders Using Low-intensity Pulsed Ultrasound Stimulation. Brain Stimulation , 8 (3), 465-473. http://doi.org/10.1016/j.brs.2014.11.017.

Ye, P. P., Brown, J. R., \& Pauly, K. B. (2016). Frequency Dependence of Ultrasound Neurostimulation in the Mouse Brain. Ultrasound in Medicine and Biology , 42 (7), 1512-1530. http://doi.org/10.1016/j.ultrasmedbio.2016.02.012.

Yoo, S. S., Bystritsky, A., Lee, J. H., Zhang, Y., Fischer, K., \& Min, B. K., et al. (2011). Focused ultrasound modulates region-specific brain activity. Neuroimage , 56 (3), 1267-1275. http://doi.org/10.1016/j.neuroimage.2011.02.058.

Yuan, Y., Zhao, Z., Wang, Z., Wang, X., Yan, J., \& Li, X. (2020). The Effect of Low-Intensity Transcranial Ultrasound Stimulation on Behavior in a Mouse Model of Parkinson's Disease Induced by MPTP. IEEE Trans Neural Syst Rehabil Eng, 28 (4), 1017-1021. http://doi.org/ 10.1109/TNSRE.2020.2978865.

Yue, P., Miao, W., Gao, L., Zhao, X., \& Teng, J. (2018). Ultrasound-Triggered Effects of the Microbubbles Coupled to GDNF Plasmid-Loaded PEGylated Liposomes in a Rat Model of Parkinson's Disease. Front Neurosci , 12 , 222. http://doi.org/10.3389/fnins.2018.00222.

Zhang, D., Li, H., Sun, J., Hu, W., Jin, W., \& Li, S., et al. (2019). Antidepressant-Like Effect of Low-Intensity Transcranial Ultrasound Stimulation. IEEE Trans Biomed Eng , 66 (2), 411-420. http://doi.org/10.1109/TBME.2018.2845689.

Zhao, L., Feng, Y., Shi, A., Zhang, L., Guo, S., \& Wan, M. (2017). Neuroprotective Effect of LowIntensity Pulsed Ultrasound Against MPP(+)-Induced Neurotoxicity in PC12 Cells: Involvement of K2P Channels and Stretch-Activated Ion Channels. Ultrasound in Medicine and Biology , 43 (9), 1986-1999. http://doi.org/10.1016/j.ultrasmedbio.2017.04.020. 
Zhao, Y. Z., Jin, R. R., Yang, W., Xiang, Q., Yu, W. Z., \& Lin, Q., et al. (2016). Using Gelatin Nanoparticle Mediated Intranasal Delivery of Neuropeptide Substance P to Enhance Neuro-Recovery in Hemiparkinsonian Rats. Plos One, 11 (2), e148848. http://doi.org/10.1371/ journal.pone.0148848.

Zhou, H., Niu, L., Meng, L., Lin, Z., Zou, J., \& Xia, X., et al. (2019). Noninvasive Ultrasound Deep Brain Stimulation for the Treatment of Parkinson's Disease Model Mouse. Research (Wash D C) ,2019, 1748489. http://doi.org/10.34133/2019/1748489.

Zhou, H., Niu, L., Xia, X., Lin, Z., Liu, X., \& Su, M., et al. (2019). Wearable Ultrasound Improves Motor Function in an MPTP Mouse Model of Parkinson's Disease. IEEE Trans Biomed Eng , 66 (11), 3006-3013. http://doi.org/10.1109/TBME.2019.2899631.

Table 1 Summary of the effects of LIFUS in PD model

\begin{tabular}{llll}
\hline Authors \& Year & Species & Experimental model & Ultrasound parameters \\
\hline Yi Yuan et al. 2020 & C57BL/6 mice & MPTP & FF 500kHz, PRF 1 kHz, DC 5\%, SD \\
Hui Zhou et al. 2019 & C57BL/6 mice & MPTP & FF 800 kHz, PRF 100 Hz, TBD 1 ms \\
Weiwei Wang et al. 2017 & C57/BL6 mice & MPTP & FF 1 MHz, TST 15min, 0.3W/cm 2. \\
Lu Zhao et al. 2017 & PC12 cells & MPP+ & FF 1 MHz, DC 20\%, PRF 100Hz, TS \\
Mrigendra Bir Karmacharya et al. 2017 & PC12 cells & MPP+ & FF 1 MHz, TST 10 min, 30, 50, or 10 \\
Lu Zhao et al. 2019 & PC12 cells & MPP+ & FF 1 MHz, DC 20\%, PRF100Hz, TS \\
\hline
\end{tabular}

FF: fundamental frequency PRF: pulsed repetition frequency DC: duty cycle TBD: time of burst duration SD: stimulation duration

ISI: interstimulus interval TST: total stimulation time

Table 2 Summary of different strategies for FUS-mediated permeabilization of the BBB in PD model 


\begin{tabular}{|c|c|c|c|c|c|c|c|}
\hline $\begin{array}{l}\text { Authors \& } \\
\text { Year }\end{array}$ & Species & $\begin{array}{l}\text { Experimental } \\
\text { model }\end{array}$ & $\begin{array}{l}\text { Ultrasound } \\
\text { parameters }\end{array}$ & $\begin{array}{l}\text { Delivery } \\
\text { vehicle }\end{array}$ & Delievable & Dose\&time & Consequence \\
\hline $\begin{array}{l}\text { Gesthimani } \\
\text { Samiotaki } \\
\text { et al. } 2015\end{array}$ & $\begin{array}{l}\mathrm{C} 57 \mathrm{BL} / 6 \\
\text { mice }\end{array}$ & - & $\begin{array}{l}\text { CF } 10 \\
\text { MHz, } \\
\text { PRF } 10 \\
\mathrm{~Hz}, \mathrm{TST} \\
60 \mathrm{~s}\end{array}$ & microbubbles & NTN & $5 \mu \mathrm{g} / \mathrm{g}$ & $\begin{array}{l}\text { FUS in } \\
\text { conjunc- } \\
\text { tion with } \\
\text { microbub- } \\
\text { bles can } \\
\text { induce } \\
\text { high levels } \\
\text { of NTN } \\
\text { bioavail- } \\
\text { ability } \\
\text { through } \\
\text { the safely } \\
\text { opened } \\
\text { BBB } \\
\text { volume, } \\
\text { and } \\
\text { increased } \\
\text { bioactiv- } \\
\text { ity, } \\
\text { indicating } \\
\text { the strong } \\
\text { therapeu- } \\
\text { tic } \\
\text { potential } \\
\text { for } \\
\text { Parkin- } \\
\text { son's and } \\
\text { other } \\
\text { neurode- } \\
\text { generative } \\
\text { diseases of } \\
\text { this non- } \\
\text { invasive } \\
\text { drug } \\
\text { delivery } \\
\text { methodology. }\end{array}$ \\
\hline
\end{tabular}




\begin{tabular}{|c|c|c|c|c|c|c|c|}
\hline $\begin{array}{l}\text { Authors \& } \\
\text { Year }\end{array}$ & Species & $\begin{array}{l}\text { Experimental } \\
\text { model }\end{array}$ & $\begin{array}{l}\text { Ultrasound } \\
\text { parameters }\end{array}$ & $\begin{array}{l}\text { Delivery } \\
\text { vehicle }\end{array}$ & Delievable & Dose\&time & Consequence \\
\hline $\begin{array}{l}\text { Chung- } \\
\text { Yin Lin et } \\
\text { al. } 2016\end{array}$ & $\begin{array}{l}\mathrm{Balb} / \mathrm{c} \\
\text { mice }\end{array}$ & MPTP & $\begin{array}{l}\mathrm{CF} \\
500 \mathrm{kHz}, \\
\text { TBD } \\
10 \mathrm{~ms}, \mathrm{DC} \\
1 \%, \mathrm{RPF} \\
1 \mathrm{~Hz}, \mathrm{TST} \\
60 \mathrm{~s}\end{array}$ & $\begin{array}{l}\text { gene- } \\
\text { liposome- } \\
\text { microbubbles }\end{array}$ & GFP/GDNF & $\begin{array}{l}27 \\
\mu \mathrm{g} ; 21 \text { days }\end{array}$ & $\begin{array}{l}\text { FUS expo- } \\
\text { suring } \\
\text { with the } \\
\text { adminis- } \\
\text { tration of } \\
\text { LpDNA- } \\
\text { MBs } \\
\text { complexes } \\
\text { synergisti- } \\
\text { cally can } \\
\text { serve as } \\
\text { an } \\
\text { effective } \\
\text { gene } \\
\text { therapy } \\
\text { strategy } \\
\text { for MPTP } \\
\text { animal } \\
\text { treatment, } \\
\text { and may } \\
\text { have } \\
\text { potential } \\
\text { for further } \\
\text { applica- } \\
\text { tion to } \\
\text { perform- } \\
\text { gene } \\
\text { therapy } \\
\text { for } \\
\text { neurode- } \\
\text { generative } \\
\text { disease. }\end{array}$ \\
\hline
\end{tabular}




\begin{tabular}{|c|c|c|c|c|c|c|c|}
\hline $\begin{array}{l}\text { Authors \& } \\
\text { Year }\end{array}$ & Species & $\begin{array}{l}\text { Experimental } \\
\text { model }\end{array}$ & $\begin{array}{l}\text { Ultrasound } \\
\text { parameters }\end{array}$ & $\begin{array}{l}\text { Delivery } \\
\text { vehicle }\end{array}$ & Delievable & Dose\&time & Consequence \\
\hline $\begin{array}{l}\text { Ling Long } \\
\text { et al. } 2017\end{array}$ & SD rats & 6-OHDA & $\begin{array}{l}\text { FF } 0.5 \\
\text { MHz, } \\
\text { TST } 30 \mathrm{~s}\end{array}$ & $\begin{array}{l}\text { pDC315 } \\
\text { nanoparticles }\end{array}$ & Nrf2 & $\begin{array}{l}0.01 \mathrm{mg} / \mathrm{kg} \\
14 \text { days }\end{array}$ & $\begin{array}{l}\text { MRI- } \\
\text { guided } \\
\text { focused } \\
\text { ultrasound } \\
\text { delivery of } \\
\text { nanomi- } \\
\text { crobubbles } \\
\text { can } \\
\text { increase } \\
\text { gene } \\
\text { transfec- } \\
\text { tion } \\
\text { efficiency. } \\
\text { Further- } \\
\text { more, } \\
\text { Nrf2 gene } \\
\text { transfec- } \\
\text { tion } \\
\text { reduce } \\
\text { reactive } \\
\text { oxygen } \\
\text { species } \\
\text { levels, } \\
\text { thereby } \\
\text { protecting } \\
\text { neurons in } \\
\text { the target } \\
\text { region. }\end{array}$ \\
\hline
\end{tabular}




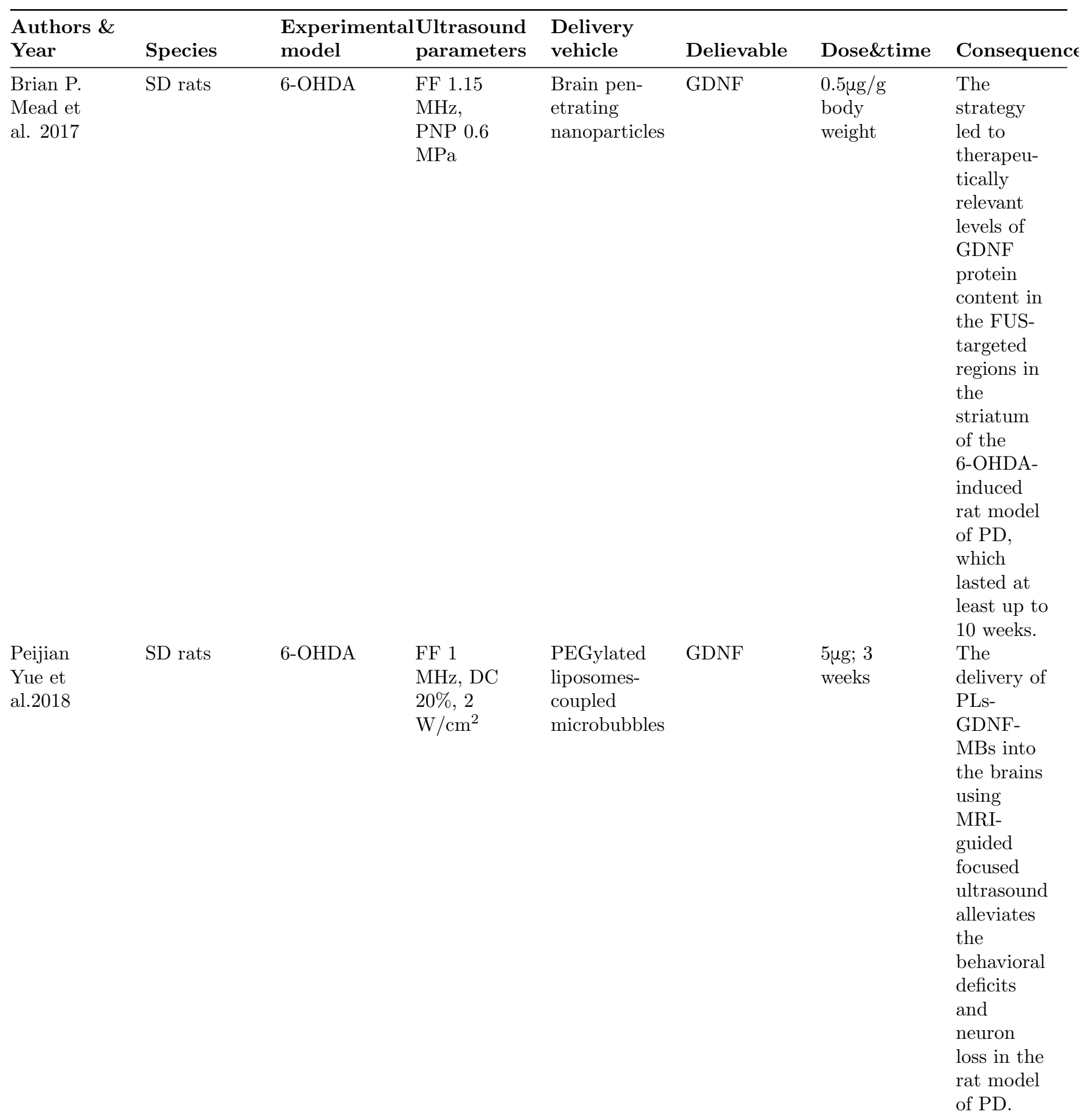




\begin{tabular}{|c|c|c|c|c|c|c|c|}
\hline $\begin{array}{l}\text { Authors \& } \\
\text { Year }\end{array}$ & Species & $\begin{array}{l}\text { Experimer } \\
\text { model }\end{array}$ & $\begin{array}{l}\text { 1Ultrasound } \\
\text { parameters }\end{array}$ & $\begin{array}{l}\text { Delivery } \\
\text { vehicle }\end{array}$ & Delievable & Dose\&time & Consequenc \\
\hline $\begin{array}{l}\text { Kristiana } \\
\text { Xhima et } \\
\text { al. } 2019\end{array}$ & $\begin{array}{l}\text { Transgenic } \\
\text { mice }\end{array}$ & $\begin{array}{l}\text { Tg mice } \\
\text { lacking en- } \\
\text { dogenous } \\
\text { murine } \\
\alpha \text {-syn but } \\
\text { expressing } \\
\text { wild-type } \\
\text { human } \\
\alpha \text {-syn }\end{array}$ & $\begin{array}{l}\text { FF } 1.68 \\
\text { MHz, } \\
\text { TBD } \\
\text { 10ms, } \\
\text { PRF } 1 \mathrm{~Hz}, \\
\text { TST } 120 \\
\text { s. }\end{array}$ & $\begin{array}{l}\text { AAV9 } \\
\text { vectors }\end{array}$ & $\begin{array}{l}\text { shRNA } \\
\text { sequence } \\
\text { targeting } \\
\text { human } \\
\alpha \text {-syn }\end{array}$ & $\begin{array}{l}1.25 \times 10^{10} \\
\mathrm{VG} / \mathrm{g}\end{array}$ & $\begin{array}{l}\text { MR- } \\
\text { guided } \\
\text { focused } \\
\text { ultrasound } \\
\text { can } \\
\text { effectively, } \\
\text { non- } \\
\text { invasively, } \\
\text { and simul- } \\
\text { taneously } \\
\text { deliver } \\
\text { viral } \\
\text { vectors } \\
\text { targeting } \\
\alpha \text { - } \\
\text { synuclein } \\
\text { to } \\
\text { multiple } \\
\text { brain } \\
\text { areas. }\end{array}$ \\
\hline $\begin{array}{l}\text { Maria } \\
\text { Eleni } \\
\text { Karakat- } \\
\text { sani et al. } \\
2019\end{array}$ & $\begin{array}{l}\mathrm{C} 57 \mathrm{BL} / 6 \\
\text { mice }\end{array}$ & MPTP & $\begin{array}{l}\text { CF } 1.5 \\
\text { MHz, } \\
\text { PRF } 10 \\
\mathrm{~Hz}, \mathrm{TST} \\
60 \mathrm{~s}, \mathrm{PNP} \\
0.45 \mathrm{MPa} .\end{array}$ & $\begin{array}{l}\text { Microbubbles, } \\
\text { AAV1- } \\
\text { CAG- } \\
\text { eGFP- } \\
\text { GDNF } \\
\text { vectors }\end{array}$ & $\begin{array}{l}\text { GDNF, } \\
\text { NTN }\end{array}$ & $\begin{array}{l}50 \mu l \\
\text { Neurturin } \\
(20 \mu \mathrm{g} / \mathrm{g} \\
\text { of body } \\
\text { mass }) \text {, } \\
100 \mu l \\
\text { diluted } \\
\text { AAV; } 12 \\
\text { weeks }\end{array}$ & $\begin{array}{l}\text { The com- } \\
\text { bination } \\
\text { of FUS } \\
\text { and intra- } \\
\text { venous } \\
\text { neu- } \\
\text { rotrophic } \\
\text { (protein } \\
\text { or gene) } \\
\text { delivery } \\
\text { attenuates } \\
\text { the } \\
\text { damage to } \\
\text { the nigros- } \\
\text { triatal } \\
\text { dopamin- } \\
\text { ergic } \\
\text { pathway, } \\
\text { by } \\
\text { allowing } \\
\text { the entry } \\
\text { of these } \\
\text { agents } \\
\text { into the } \\
\text { brain } \\
\text { parenchyma. }\end{array}$ \\
\hline
\end{tabular}




\begin{tabular}{|c|c|c|c|c|c|c|c|}
\hline $\begin{array}{l}\text { Authors \& } \\
\text { Year }\end{array}$ & Species & $\begin{array}{l}\text { Experimental } \\
\text { model }\end{array}$ & $\begin{array}{l}\text { Ultrasound } \\
\text { parameters }\end{array}$ & $\begin{array}{l}\text { Delivery } \\
\text { vehicle }\end{array}$ & Delievable & Dose\&time & Consequence \\
\hline $\begin{array}{l}\text { Chung- } \\
\text { Yin Lin et } \\
\text { al. } 2020\end{array}$ & $\begin{array}{l}\text { Balb/c } \\
\text { mice }\end{array}$ & МPTP & $\begin{array}{l}\text { FF } \\
1.0 \mathrm{MHz}, \\
\text { TBD } \\
\text { 10ms, } \\
\text { PRF } 10 \\
\text { Hz, TST } 3 \\
\text { min. }\end{array}$ & $\begin{array}{l}\text { Mcrobubble } \\
\text { (MB)- } \\
\text { liposome } \\
\text { complex }\end{array}$ & $\begin{array}{l}\text { GDNF, } \\
\text { BDNF, } \\
\text { and } \\
\text { concurrent } \\
\text { GDNF/BDNF } \\
\text { gene } \\
\text { delivery }\end{array}$ & $\begin{array}{l}60 \mu \mathrm{g} ; \\
\text { twice a } \\
\text { week for } 3 \\
\text { weeks }\end{array}$ & $\begin{array}{l}\text { Either } \\
\text { BDNF or } \\
\text { GDNF } \\
\text { gene } \\
\text { delivery } \\
\text { via the } \\
\text { UTMD } \\
\text { system } \\
\text { provides a } \\
\text { neuropro- } \\
\text { tective } \\
\text { effect with } \\
\text { evidence } \\
\text { of } \\
\text { improve- } \\
\text { ments of } \\
\text { behavioral } \\
\text { deficits, } \\
\text { decreased } \\
\text { calcium } \\
\text { influx, } \\
\text { GFAP and } \\
\text { caspase } 3 \\
\text { expres- } \\
\text { sion, and } \\
\text { rescued } \\
\text { dopamin- } \\
\text { ergic } \\
\text { neuronal } \\
\text { loss. }\end{array}$ \\
\hline
\end{tabular}

CF: center frequency FF: fundamental frequency PRF: pulsed repetition frequency DC: duty cycle TBD: time of burst duration

SD: stimulation duration ISI: interstimulus interval TST: total stimulation time

\section{Figure legends}

FIGURE 1. The strategy and effect of low intensity focused ultrasound in the treatment of Parkinson's disease(PD). 1.Low intensity focused ultrasound (LIFUS) combined with microvesicles opens the blood-brain barrier (BBB): Taking an animal model of PD as an example, dopamine neurons secret less dopamine in mice with PD. Under the combined action of tail vein injection of microbubbles and the appropriate low intensity focused ultrasonic parameters, the blood brain barrier at the focused site is opened. 2.LIFUS acts on specific parts of the mice brain: At present, the relevant research of LIFUS has many choices for the site of action, such as the motor cortex, substantia nigra, striatum and other specific sites. LIFUS can non-invasively, repeatably and temporarily opens the BBB of the brain by adjusting appropriate ultrasound parameters. 3. microvesicles or nanoparticles deliver relevant genes or therapeutic drugs: The blood brain barrier at the focused site is opened, and then various microvesicles or nanoparticles (are injected into the tail vein to deliver relevant genes or therapeutic drugs such as polymeric nanoparticle,dendrimer,nanogel,magnetic nanoparticle,viral-based nanoparticle,micelle and liposome, which 
can enter the relevant parts of the brain, such as the substantia nigra and striatum. 4.The effect of the LIFUS-mediated permeabilization of the BBB : Therapeutic substances typically pass through an open blood-brain barrier in two ways: the paracellular pathway and the transcellular pathway. Tense junctions are an important component of BBB and play an important role in regulating paracellular permeability. Protein expressed by endothelial cells plays an important role in mediating the transport of therapeutic substances across cellular pathways. Therapeutic large and small molecules entered by opening the blood-brain barrier may act on dopamine neurons to improve motor symptoms by increasing dopamine secretion.

\section{Hosted file}

table.docx available at https://authorea.com/users/424618/articles/529657-the-effect-andmechanism-of-low-intensity-focused-ultrasound-in-the-treatment-of-parkinson-s-disease

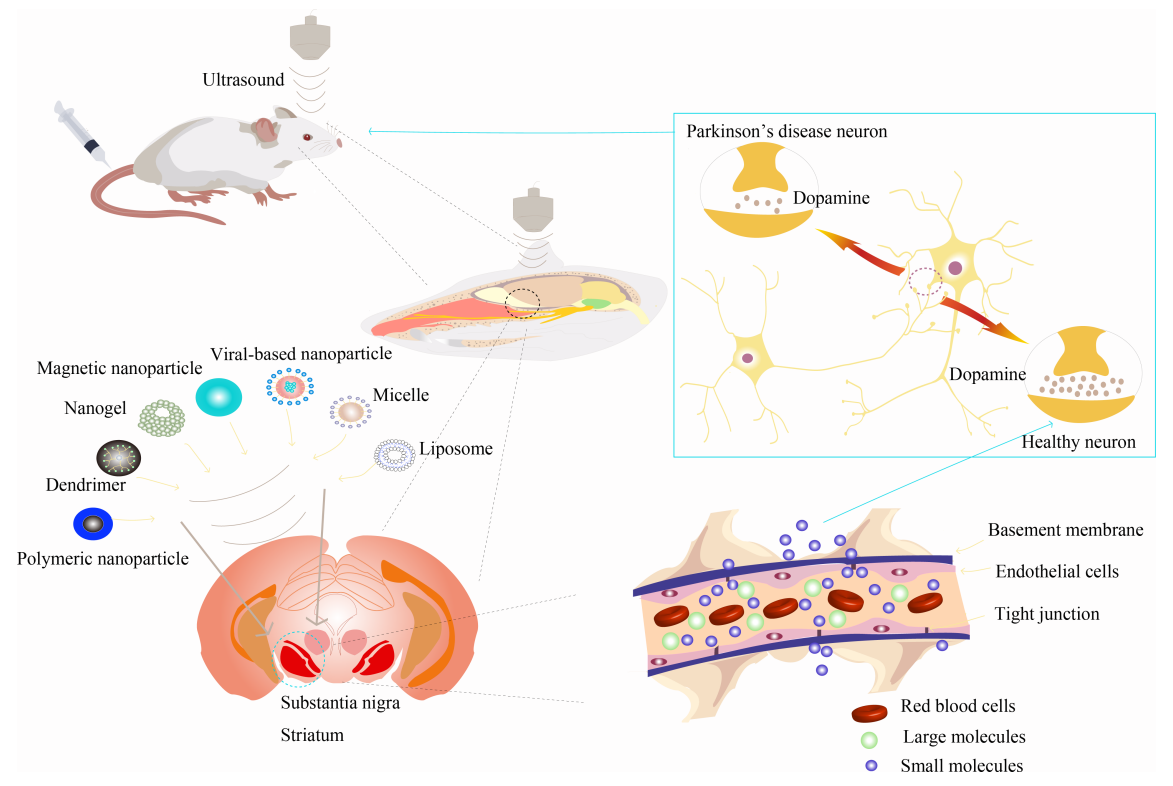

